\title{
Lymphocyte subpopulations in patients with hydroxocobalamin responsive megaloblastic anaemia
}

\author{
MA WODZINSKI, MJ FORREST, D BARNETT, ACK LAWRENCE \\ From the Department of Haematology, Northern General Hospital, Sheffield S5 7AU
}

SUMMARY Lymphocyte subpopulations and intrinsic factor and gastric parietal cell antibodies have been measured in 23 patients with megaloblastic anaemia who responded to treatment with hydroxocobalamin. The ratio of helper (OKT4) to suppressor (OKT8) lymphocytes was significantly increased in patients with intrinsic factor antibody compared with those who lacked the antibody. No such correlation was found for gastric parietal cell antibody. Alterations in the lymphocyte helper to suppressor (OKT4:OKT8) ratio may be associated with pernicious anaemia.

Megaloblastic anaemia due to pernicious anaemia is thought to be caused by autoimmune mechanisms.' The blocking type of intrinsic factor antibody occurs in about $55 \%$ of cases; its presence in a case of megaloblastic anaemia due to low vitamin $\mathrm{B}_{12}$ concentrations can be taken to be diagnostic of pernicious anaemia. ${ }^{2}{ }^{3}$

The availability of monoclonal antisera against specific determinants present on $\mathrm{T}$ lymphocytes ${ }^{45}$ has provided a reliable method for investigating $T$ cell populations in immunological disorders. Of these antibodies, Leu- 4 reacts with all peripheral T lymphocytes, Leu-12 reacts with all B lymphocytes, OKT4 with the helper/inducer population, and OKT8 with cytotoxic/suppressor cells. We have investigated the ratio of the OKT4 to OKT8 positive lymphocytes in patients with megaloblastic anaemia who responded to hydroxocobalamin injections.

\section{Material and methods}

\section{SELECTION OF PATIENTS}

Patients who were in remission from megaloblastic anaemia responsive to injections of hydroxocobalamin were studied. Each patient had a documented macrocytic anaemia which had responded to hydroxocobalamin alone; patients who had received folic acid or iron treatment before a clear response to hydroxocobalamin were excluded from the study. All patients were receiving maintenance hyd- roxocobalamin and had normal peripheral blood counts at the time of study.

The following blood tests were performed: full blood count and automated differential count using the H6000 counter (Technicon Ltd), urea, electrolytes, calcium, alanine transferase, $\gamma$-glutamyl transpeptidase, antinuclear factor, mitochondrial antibody, smooth muscle antibody, gastric parietal cell antibody, and intrinsic factor antibody.

\section{SELECTION OF NORMAL SUBJECTS}

A normal range was established using 17 apparently healthy medical laboratory staff, all of whom had normal white cell counts and differential, biochemistry results, serum vitamin $B_{12}$ values, and no detectable autoantibodies.

\section{GASTRIC INTRINSIC FACTOR ANTIBODY TEST}

The method employed ${ }^{6}$ incorporated cobinamide ( $\mathrm{Cbi}$ ) to block the $\mathrm{R}$ protein present in normal human gastric juice. Samples with high vitamin $B_{12}$ concentrations were exposed to haemoglobin coated charcoal to remove any free $B_{12}$. Antibody concentrations are expressed as nanogram units $/ \mathrm{cm}^{3}$; one nanogram unit is that amount of antibody which will block the binding of $1 \mathrm{ng}$ of cobalamin.

\section{LYMPHOCYTE SUBPOPULATIONS USING}

MONOCLONAL ANTIBODIES

Peripheral blood samples (from both patients and controls) were collected into edetic acid. The blood was then layered on to the density separating medium Lymphoprep (Nyegaard, UK Ltd), and centrifuged at $800 \mathrm{~g}$ for $30 \mathrm{~min}$. Lymphocytes were 
then recovered from the interface of the Lymphoprep. The cells were washed three times in phosphate buffered saline and the white cell count adjusted to approximately $5.0 \times 10^{9} / 1$. The viability of lymphocytes was assessed using the trypan blue exclusion test; greater than $90 \%$ viability was achieved on all specimens. Conventional indirect immunofluorescence $^{7}$ was carried out on the lymphocytes using four monoclonal antibodies: Leu-4 and Leu-12 (Becton-Dickinson, Lab Impex, Middlesex); OKT4 and OKT8 (Ortho-Diagnostics Systems Inc, Rari$\tan , \mathrm{NJ})$.

Leu- 4 reacts with the majority of peripheral blood lymphocytes that form rosettes with sheep red blood cells but does not react with B lymphocytes. Similarly, Leu-12 reacts with all peripheral blood lymphocytes of $B$ cell lineage as defined by the presence of $\kappa$ and $\lambda$ light chains but does not react with $T$ lymphocytes.

OKT4 and OKT8 react with the subgroups of T lymphocytes helper and suppressor, respectively.

\section{Results}

Patients with intrinsic factor antibodies had higher OKT4 to OKT8 ratios than those without. The mean OKT4 to OKT8 ratio for intrinsic factor positive patients was $4 \cdot 22$, which was significantly differ-

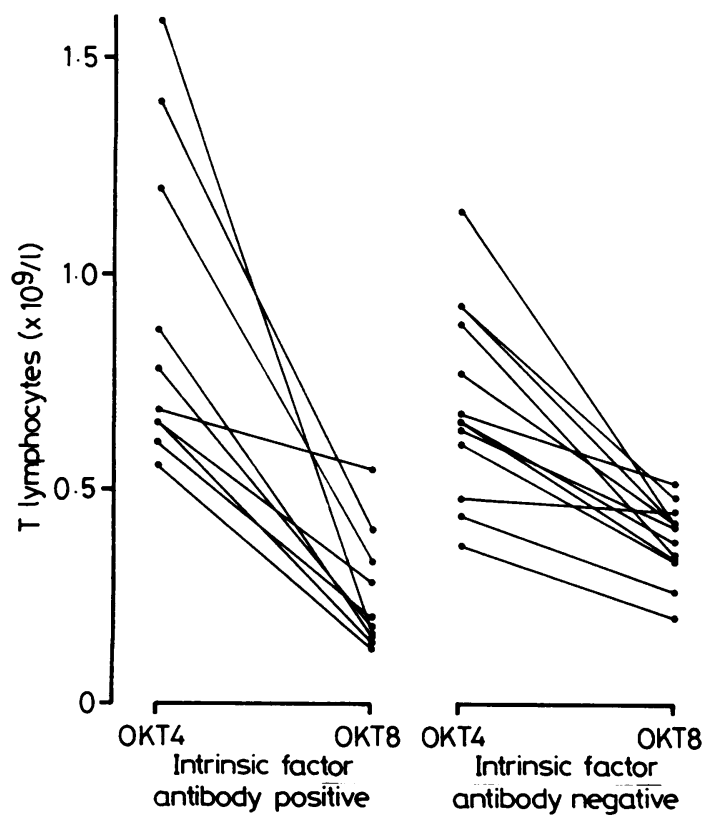

Absolute numbers of OKT4 and OKT8 positive lymphocytes in patients with and without intrinsic factor antibody. ent $(p<0.01)$ from the mean of 1.88 for intrinsic factor negative patients. Although eight of 10 patients with intrinsic factor antibody had a ratio greater then $3 \cdot 0$, the antibody negative patients and the controls all had ratios less than 3.0.

The absolute numbers of helper (OKT4) and suppressor (OKT8) cells are shown in the Figure. There was no significant difference in the number of helper cells for patients with or without intrinsic factor antibodies; however, there was a significant difference for suppressor cells $(p<0.01)$.

No significant difference was found between patients positive or negative for the gastric parietal cell antibody, either for the OKT4 to OKT8 ratio or absolute lymphocyte counts.

None of the patients had an overt autoimmune disease; neither did they have significant antibody titres to nuclear, smooth muscle, or mitochondrial antibodies. There were no significant abnormalities in urea, creatinine, bilirubin, alanine transferase or $\boldsymbol{\gamma}$-glutamyl transpeptidase values.

A normal range established using results from the 17 healthy members of staff yielded a mean OKT4 to OKT8 ratio of 1.76 and standard deviation of 0.5 , which correlates well with the patients without intrinsic factor antibody.

\section{Discussion}

It has previously been shown that OKT4 to OKT8 ratios are increased in patients with a variety of autoimmune diseases. ${ }^{8} \mathrm{~A}$ recent report of increased ratios in three patients with pernicious anaemia who had the intrinsic factor antibody suggests this may also be true of pernicious anaemia. ${ }^{9}$

Our study of 23 patients in remission from hydroxocobalamin responsive megaloblastic anaemia confirms and extends these findings. We found a significantly higher OKT4 to OKT8 ratio in patients who possessed the intrinsic factor antibody, but no correlation with the presence of the gastric parietal cell antibody. These findings suggest a correlation between autoimmune activity and intrinsic factor antibody but not with gastric parietal cell antibody.

Those patients with OKT4 to OKT8 ratios greater than 3.0 possessed the intrinsic factor antibody; patients who did not possess this antibody had ratios less then 3.0. It would appear that patients with megaloblastic anaemia responsive to hydroxocobalamin and OKT4 to OKT8 ratios greater than 3.0 will be positive for intrinsic factor antibody.

A correlation between lymphocyte subpopulation in the gastric mucosa and pernicious anaemia has been reported, ${ }^{10}$ with a suggestion that alterations in the lymphocyte subpopulation may be implicated in the aetiology of the disease. Our findings of a raised 
OKT4 to OKT8 ratio in the peripheral blood lymphocytes of most patients with pernicious anaemia who possess the intrinsic factor antibody also provides evidence that immune factors are involved.

We thank Dr MJ Brown for allowing us to study some of his patients and Dr A Milford Ward and Dr Owen for their help with the immunological and biochemical tests.

\section{References}

' Hardisty RM, Weatherall DJ. Blood and its disorders. Oxford: Blackwell Scientific, 1983.

${ }^{2}$ Chanarin I. The megaloblastic anaemias. 2nd ed, Oxford; Blackwell Scientific, 1979:362-4.

${ }^{3}$ Lindenbaum J. Status of laboratory testing in the diagnosis of megaloblastic anaemia. Blood 1983;61:24.

${ }^{4}$ Reinhertz EL, Schlossman SF. Regulation of the immune response-inducer and suppressor T-lymphocyte subsets in human beings. $N$ Engl J Med 1980;303:370-3.
${ }^{5}$ Back MA, Bach JF. The use of monoclonal anti T antibodies to study $\mathrm{T}$ cell imbalances in human diseases. Clin Exp Immunol 1981;45:449-56.

- Gräsbeck R, Kouvonen I. The materials and processes of intestinal transport. In: Hall CA, ed. The cobalamins. Edinburgh: Churchill-Livingston, 1983;79-108.

7 Janossy G. Membrane markers in leukaemia. In: Catovsky D, ed. The leukaemic cell. Edinburgh: Churchill-Livingston, 1982:129-83.

${ }^{8}$ Raeman F, Deacock W, De Beukelaar T, De Cree J, Verhaegen $H$. Enumeration of $T$ lymphocytes and $T$ lymphocyte subsets in auto-immune disease using monoclonal antibodies. Clin Exp Immunol 1981;45:475-9.

"Imamura N, Fujimura K, Kuromota A. Lymphocyte subpopulations in pernicious anaemia (letter). $N$ Engl $J$ Med 1984;311:56.

"Kaye MD, Whorwell PJ, Wright R. Gastric mucosal lymphocyte sub-populations in pernicious anaemia and in normal stomach. Clin Immunol Immunopathol 1983;28:431-40.

Requests for reprints to: Mr D Barnett, Department of Haematology, Northern General Hospital, Herries Road, Sheffield S5 7AU, England. 